\title{
TRANSVERSAL SKILLS FOR THE IMPLEMENTATION OF COMPETENCE APPROACH DURING A MUSIC PEDAGOGY PROCESS AT PRIMARY SCHOOL
}

\author{
Ilze Vilde \\ Jazeps Vitols Academy of Music, Latvia
}

\begin{abstract}
Expertise-based (competence) approach is one of the approaches in pedagogy which in the $21^{\text {st }}$ century can be applied to develop important value-based knowledge, skills and habits. Transversal skills help learners to use knowledge in a real-life context, be ready to take on responsibility for their own learning, constituting a complex achievement, and strengthening the link between knowledge and personal experience. These skills can be acquired by purposefully integrating them with the core skills in all subjects, music including. Transversal skills include such components as: cooperation, creative and entrepreneurial ability, civic participation, critical thinking and problem solving, digital literacy, and self-guided learning skills. It is essential to bring the above-mentioned skills into focus in music pedagogy to substantiate them theoretically and give a practical guidance how they can be seen in a pedagogical reality and develop them within the frame of music teaching in primary school.

Research aim: to describe and substantiate how to enhance the development of transversal skills by applying competence approach during a music pedagogy process at primary school. Materials and methods: this paper will provide the analysis of theoretical literature and education documents on the competence approach, examine possibilities of developing transversal skills in music at Music Primary School. Theoretical findings will be brought into foreground in connection with the pedagogical experience obtained while teaching at Jazeps Vitols Latvian Academy of Music and giving music lessons in general education institutions.
\end{abstract}

Keywords: transversal skills, cooperation, creative and entrepreneurial ability, critical thinking, digital literacy, self-guided learning skills, competence approach, music pedagogical process at primary school.

\section{Introduction}

Transversal competences have been identified as vital to $21^{\text {st }}$ century life and have been given a prominent place in the knowledge society and 
lifelong learning (Larraz, et al., 2017). Transversal competences are also understood as $21^{\text {st }}$ century skills and are necessary for citizens to be successful and competitive in the global labour market, as well as to be responsible and contribute to society (Ananiadou \& Claro, 2009). Therefore, Latvia continues the initiated reform of the content of education at all levels of education, moving to the expertise or competence approach.

Expertise-based or competence approach involves a vision of what kind of learners we would like to see - responsible and active public figures, self-confident personalities who respect and care for themselves and other people, creative doers and experts on development for whom learning has become a habit, and loyal to their country. Implementation of expertise-based approach requires a complex learner's performance which comprises knowledge, skills and habits (Olina et al., 2018). To achieve the set aim, the educational content needs regularity and integrity for creating a uniform understanding about the components of educational content.

The implementation of the expertise-based approach facilitates the development and improvement of basic skills which interchange in different combinations with the transversal skills, crossing subject borders and covering the whole study process. Within the frame of music study content, the major parts of music study content remain constant. They include such content components as:

1. Practical music making and creative activity, comprising: singing, scansion, beating rhythm, playing musical instruments, composing music and improvisation;

2. Mastering language of music to understand staff notation, the importance of music expression means for creating images, as well as familiarizing oneself with various staff of performers during the process of listening to music;

3. Learning music culture, historical styles and genres of music, as well as studying composers and their compositions in a creative activity, listening to and learning to understand music (Fenhane et al., 2019).

The transversal skills have to be acquired purposefully, systematically and step by step in all subjects, including music. Zane Olina is of opinion that transversal skills encompass a tool for thinking and doing or an aggregate of strategies for a purposeful and effective action, so that the learners could thoroughly study and acquire the educational content, gaining in the result deeper and more comprehensive knowledge. The development of transversal skills is simultaneously also a significant goal of education, so that the learners would be able to act similarly in new, unfamiliar reallife situations (Olina et al., 2018). Transversal skills help learners acquire knowledge, skills and habits, thus constituting a complex achievement and strengthening a link between knowledge and personal experience. 
This issue is important at all levels of education, including primary school, as the acquisition of transversal skills provides the basis for sustainable education. The goal of sustainable education is a person who lives not only in harmony with nature and other cultures, but also knows how to fully realize himself in society and the economy, ensuring the long-term and prudent use of resources. Such a person understands local problems, can see them in a global context, understands and respects other cultures, maintains healthy relationships at all levels of society, promotes economic development, thus promoting social sustainability (Medne \& Jansone Ratinika, 2019). In the context of Latvian education, the possibilities of continuous skills development in music education have not been analysed so far, pedagogical experience in the implementation of the competence approach in the subject of music at the primary school stage has not been analysed and theoretically substantiated. Analysing the research problem and topicality, the aim of publication was determined to analyze and theoretically substantiate the way how to foster the development of transversal skills by implementing the expertise-based approach to the subject of music in a primary school (grades $1-6$ ) and how the transversal skill can be integrated with the basic skills of acquiring music.

\section{Research Methodology and process}

The study on the promotion of transversal skills in music lessons in primary school has been implemented in a qualitative methodology and an interpretive research paradigm. The interpretive research paradigm was chosen because its fundamental idea is to accept the relativist ontology (i. e., people have different interpretations of social reality and its phenomena) and the subjectivist epistemology (i. e., people construct knowledge of social reality phenomena, experiencing and interpreting them) (Creswell, 2007). Within the framework of this research, the dimension of relative ontology is formed by the analysis of theoretical literature and documents regulating education of the Republic of Latvia on expertise (competences) approach, in the context of transversal skills development in the subject of music. In turn, the axis of subjective epistemology is formed by the actualization of theoretical findings in connection with the pedagogical experience gained in conducting pedagogical practice at the Jāzeps Vìtols Latvian Academy of Music and conducting music lessons in general education institutions.

The category of description form has been chosen to represent the content and form of the research. A set of transversal skills was chosen as the description categories: cooperation, creativity, and entrepreneurship, critical thinking and problem solving, digital skills, and self-directed learning 
skills. The categories of descriptions reflect the diversity of understanding of a phenomenon at the collective level rather than the individual level. The phenomenon in this study describes each transversal competence.

\section{Enhancing the Development of Transversal Skills at Music Lessons in Primary School}

Transversal skills encompass a wide range of different skills: skills of cooperation, creativity and entrepreneurship, of critical thinking and problem solving, digital literacy and self-guided learning. The most essential skills that can be properly developed at teaching music are creativity and entrepreneurship, as well as cooperation. Creativity and entrepreneurship are a process during which new ideas useful for a human or a group of people emerge, while entrepreneurship enables to put these ideas into practice, achieving one's own and cooperation aims (from materials Skola2030[School2030]). The development of these skills can be fostered by joint music making and music learning where the learners are given the opportunity to implement their creative ideas. Cooperation manifests itself in the interaction between music teacher's teaching and learners' learning, which is promoted by involving learners in an active musical activity. Musical activity includes such kinds of activity as listening to music, musical-rhythmical movements, singing and scansion, plying musical instruments, and these activities are being related to the acquisition of a music language and cultural values, thus improving learners' knowledge, skills and attitude to music. Cooperation during the process of joint music making manifests itself as a skill of listening, interaction, a creative experiment and response to the impulses of music. Therefore, when making music collectively, it is essential to listen to the melody, and to hear oneself and other participants' playing and singing. This testifies to the fact that skills of cooperation in a joint music making are closely related to learners' musicality and its development. It is vital to understand that the quality of music making can be affected not only by the level of learner's musical abilities and skills, but also by the interpersonal communication, which contributes to creating a psychological comfort (Vilde, 2013). Therefore, during the educational process, it is advisable to ask learners to take into consideration one another's opinion, to adjust one's own activity and way of communication to those of other people, since this contributes to a positive cooperation for achieving common goals.

At setting pedagogical goals, learner's individual features should be taken into account by the teacher (Zariņš, 2003). Practice shows that learners may have different interests, skills and developmental level. For each learner, musical development occurs in its own tempo and at the level 
achievable by them, consequently, the results will always differ. This is why the process of musical pedagogy requires adopting an individualized and differentiated approach where learners' typical differences, interests and needs are taken into consideration. Individualization and differentiation of musical activity are being brought into focus because they provide broader opportunities for the development of learner's individual abilities, improvement of learner's knowledge and skills and their self-realization during music studies (Vilde, 2009).

A creative self-expression is the ability to express one's perception of life, understanding and oneself in this world. At music lessons, learners can express themselves as music performers, listeners or composers of music, and as experimenters. The diverse learners' activities during music studies promote expressing their individual potential in music, i. e. the skill of singing, beating rhythm, playing musical instruments, improvising, and composing melodies and rhythms (Vilde, 2010). Consequently, to provide learners with creative self-expression opportunities, a teacher has to organize music studies in such a way that every learner should be given the opportunity to broaden their experience and to demonstrate it to other people in a creative activity. Dainis Zariňš considers that only a creative activity gives infinite opportunities for the development, since knowledge and skills acquired by music making create an impact on human's thinking and attitude, which shows also in the activities of other spheres and processes (Zariňš, 2003).

Critical thinking and problem solving are skills by means of which learners can express and substantiate their attitude based on reliable facts, can face challenges, offer solutions and undertake implementing ideas (from materials of Skola 2013). Critical thinking is necessary, for example, at acquainting oneself with the wide world of music. The artistic content of music may reflect cultural values of single persons, groups or the whole society - norms, traditions, symbols, moral and system of viewpoints as well as a life style (Campbell, 2018).

Within the framework of education, critical thinking is interpreted as the understanding about productive thinking, as a pedagogical approach or as an aggregate of learning and teaching methods whose aim is to promote independent thinking, considering it to be the opposite to a mechanical memorizing, repetition and use of ready-made models. Critical thinking can also be interpreted as a method of forming judgements for the adoption of meaningful and responsible decisions in both educational and social fields (Rubene, Svece, 2018). The nature of critical thinking is an understanding-oriented way of thinking which during the pedagogical process is fostered by asking questions, when learners are encouraged to think, express and substantiate their attitude. In theories (Vigotskis, 2002), language is 
viewed as an essential element of a human's thinking process, since trough language we think and obtain information. Therefore, a dialogue held between two learners or between a teacher and a learner contributes greatly to the exchange of opinions and to obtaining new information accumulated at exploring the world around us, including that of music. By means of a dialogue, a teacher may stimulate learners to analyze music and learn music expression means, as well as express their feelings and judgements. For this to happen, questions in a dialogue are to be asked by degrees and purposefully - starting with already known and understandable concepts and passing over to new and unclear notions, thus directing learners towards acquiring new information (Vilde, 2013). Robert Fisher thinks that a good question is a question that gives intellectual stimulation. This contributes to provoking a cognitive conflict which, in turn, helps children move to a more advanced developmental stage. A good question can provide children with a structural support for the acquisition of new knowledge (Fišers, 2005).

To enhance the development of critical thinking, it is advisable to employ a three-phase model which includes phases of stimulation, comprehension and reflection (Pavula, 2008). Such model is especially appropriate for developing the skill of analyzing music (heard) which encompasses the ability to focus on listening to music and perceive expression means and character of music. This is the skill enabling to identify specific features of music by ear, to define and compare those which are related to understanding a music language and concept (Vilde, 2013). During the phase of stimulation, it is essential to promote learners' cognitive activities, stimulating them to acquire something new on the basis of a previously acquired material. For instance, before listening to a composition, to focus learners' attention and perception, it is necessary to give assignments on listening to music, giving them directions - what is to be listened to, what is to be paid attention to and where the answers to questions can be looked for. The phase of comprehension is an independent learners' activity learners attentively listen to and analyze the music heard according to the given criteria (e. g. tempo, dynamics, musical instruments etc.), compare it with other compositions, learn to creatively use the obtained information in a new situation. During the phase of reflection learners, supported by a teacher, evaluate the obtained information, draw conclusions, and substantiate their attitude.

Results achievable by critical thinking and problem solving involve a vision that learners purposefully explore, analyze, assess and combine different kind of information and situations, understand their context; they also identify and formulate the problem, offer their solutions to it and decide to implement them (Skolēniem plānotie sasniedzamie rezultāti caurviju prasmēs, 2018). 
Digital literacy is a skill of a responsible use of digital technologies in a daily life for obtaining, employing and creating knowledge, as well as a skill to fulfil tasks and solve problems, jointly use the content created by themselves and other people, safely communicate and cooperate with other people in a digital environment. Digital literacy includes the ability to critically and constructively use information in technology studies and during leisure time - to cleverly use the opportunities given by the technologies, use them with great responsibility and create one's own digital solutions (Olina et al., 2018). A meaningful use of information technology tools and resources contributes to more effective learning, since the digital environment allows looking at the specific problem from diverse aspects. In a digital environment, it is possible to create works and construct knowledge by learning from examples of good practice (Abbott, Townsend et al., 2009; Daniela, 2018).

Including digital means in the process of music studies along with traditional teaching materials makes it possible to up-date educational environment, use innovative and interactive teaching methods and individualize the teaching process - to customize education content to every learner's level of knowledge and individual needs, providing a feedback. During music studies, this skill gets improved by teaching learners to use digital technologies for the acquisition of knowledge and skills of music with great responsibility and effectively. At planning and conducting music lessons, it is advisable to use technologies and digital resources not only for the visualization of educational content, but also for constructing and modelling knowledge, for a collective and individual music making as well as for creating new works.

To implement the expertise-based approach, it is essential to develop self-guided learning skills which in music studies are applied in accordance with learners' age and content of education. Theories interpret selfguided learning as a process during which learners are able to activate and use tools that regulate thinking, emotional states and behavior in order to systematically direct themselves towards achieving study goals (Aleven \& Azevedo, 2013; Cleary, 2018). To develop this skill, it is necessary to involve learners in the process of planning music studies, as well as of monitoring and assessing learners' work.

In a self-guided learning process, an important role is given to the phase of planning teaching/learning work, when the aim, understandable for learners, is set, tasks and strategies are offered so that the learners would exactly know how they will learn and what they will gain from it. To ensure the implementation of this process, it is vital to formulate learning strategies for achieving the aim adequate to learners' level of education, to offer steps for fulfilling the task and clear assessment criteria, as well as to 
promote the involvement of learners in working out these criteria and in assessing learning/teaching work and its outcomes.

During the phase of monitoring, learners implement the plan discussed before and move towards the set aim, making use of learning strategies. In this phase, it is important that learners themselves should monitor their learning and progress in fulfilling assignments. In the phase of assessment, learners learn to comprehend how successful they have been at achieving the educational aim, and which methods have helped them to do it. Therefore, the role of self-evaluation carried out by the learners during the educational process is very great, since doing this, the learners acquire skills of assessing the way they have learned as well as their achievements in music according to the established and well understandable criteria. Selfevaluation enables the learners themselves to find answers to such questions as: is the aim achieved? What helped and what hindered this process? What can be done to improve the learning outcomes? If learners themselves assess the work they have done, their cognitive abilities and skills, related to the process of music making, get promoted - skill of singing, beating rhythm, improvisation. This can be achieved, if singing songs by degrees or notes, beating rhythm and composing accompaniment etc., learners themselves learn to discover mistakes and correct them (Vilde, 2013).

Planning, monitoring and evaluating are effective, if learners are actively involved in reflection. Theories interpret reflection as the process of thinking oriented towards awareness, analysis and understanding about one's deeds, behavior, language, experience, feelings, abilities and attitudes while looking for a solution. Both as a process in which one evaluates one's actions from various aspects and learns from evaluation, respectively, in reflection the child develops both his/her ability to evaluate his / her wishes and actions, and the ability to reflect on the result (Medne, 2019). The analysis of a pedagogical experience allows concluding that reflection helps learners to deeper understand their learning, to see its strong and weak sides, as well as be aware of and control their own behavior, emotions, to improve their attitudes and mutual relationships, and to understand values. Consequently, reflection encompasses all stages of self-guided learning. During the pedagogical process, reflection can be encouraged by questions, for example, at the stage of planning - what is my aim? What strategy shall I use? How much time and resources shall I need? At the stage of monitoring - Do I understand what I am doing? Shall I manage to achieve the aim? Do I know how to use resources? At the stage of evaluation - What helped me and what hindered to fulfil the assignments? Do the results correspond to the set aims? By promoting learners' cognitive activity, reflection is being stimulated, which in general is essential when expertise-based approach is adopted. The summary of 
findings on self-guided learning components in the pedagogical process is given in Fig.1.

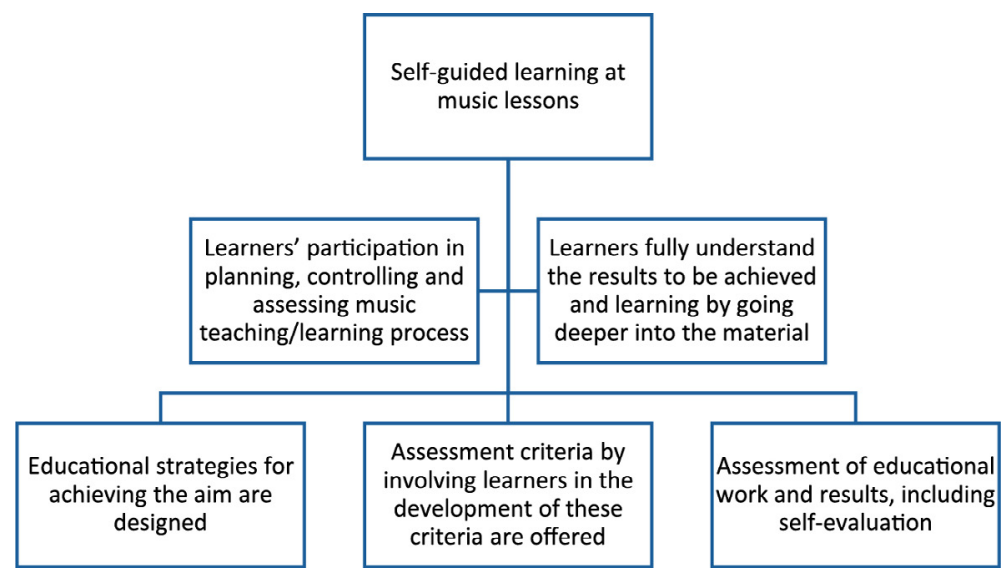

Figure 1. Components of promoting a self-guided learning

\section{Results}

The analysis of transversal skills and the way the development of these skills can be fostered in the process of music pedagogy, as well as conducting and analysis of music lessons at primary school lead to the conclusions as follows, Expertise-based or competence approach:

The most essential transversal skills in music studies are creativity, entrepreneurship and cooperation. At music lessons in primary school, the development of these skills is fostered by music making, where learners are provided the opportunity to implement their creative ideas. At music lessons learners may show themselves as music performers, listeners or music composers as well as experimenters.

Critical thinking helps learners understand and evaluate the context of musical culture, images and content of a composition. The nature of critical thinking is an understanding-oriented way of thinking which during a pedagogical process can be facilitated by questions, when learners are encouraged to think and express their attitude and substantiate it.

Digital literacy includes the ability to critically and constructively use opportunities offered by technologies, employ them with full responsibility and create new digital solutions of one's own. During music studies, this skill is improved by teaching the learners to effectively and with great responsibility use digital technologies for reinforcement of their knowledge and skills of music, as well as for a collective and individual music making. 
In the process of self-guided learning, it is essential for learners to reflect on learning, i. e. to express their opinion about learning activities and outcomes, participating in the process of planning, monitoring and assessment. To purposefully implement a self-guided learning process and get good results, learners have to analyze learning situations, set meaningful learning goals and determine which learning strategy is most suitable for them.

\section{References}

Abbott, I., Townsend, A., Johnston-Wilder, S.,\& Reynolds, L. (2009). Literature Review; Deep learning with technology in 14 to 19-year-old learners. Coventry (UK): British Educational Communications and Technology Agency (Besta).

Aleven, V., Azevedo, R. (2013). Metacognition and Learning Technologies: An Overview of Interdisciplinary Research. New York, NY: Springer.

Ananiadou, K., Claro, M. (2009). $21^{\text {st }}$ century skills and competences fornew millenniumlearners in OECD countries. http://www.oecd.org/officialdocuments/publicdisplaydocumentpdf/? cote $=\mathrm{EDU} / \mathrm{WKP}(2009) 20 \&$ doclanguage $=$ ne

Campbell, P. S. (2018). Music, Educations, and Divesity: Bridging Cultures and Communities, Teachers College Press.

Cleary, T. J. (2018). The Self - Regulated Learning Guide, New York: Routledge.

Creswell, J. W. (2007). Research design. Qualitative and mixed methods approaches. London: Sage.

Daniela, L. (2018). Smart Pedagogy for Technology-Enhanced Learning. In: Daniela L. (Ed.) Didactics of Smart Pedagogy. Cham: Springer.

Fenhane, A., Fjodorova, A., Godina, I., Nelsone, I., Vilde, I. (2019). Mācību programmu paraugi pamatizglitībā, Mūzika 1.-9.klasei. [Basic education Curricula. Music Grades 1-9] Iegūts no https://mape.skola2030.lv/resources/312

Fišers, R. (2005). Mācīsim bērniem mācīties. [Let's Teach Children to Learn] Rīga: Raka.

Larraz, N., Vázquez, S., \& Liesa, M. (2017). Transversal skills development through cooperative learning. Training teachers for the future. On the Horizon, 25(2), 85-95. doi:10.1108/OTH-02-2016-0004.

Medne, D. (2019). Everyday Pedagogical Support in Communication. International Journal of Smart Education and Urban Society (IJSEUS) 10(4). ISSN: 2574-8254, EISSN: 2574-8270, DOI: 10.4018/IJSEUS. https://www.igi-global.com/article/ everyday-pedagogical-support-in-communication/236627

Medne, D., Jansone-Ratinika, N. (2019). Professional Mastery of Academics in Higher Education: the Case of Latvia. Innovations, Technologies and Research in Education, 2019, 718, 591-600. https://www.apgads.lu.lv/fileadmin/user_upload/lu_portal/apgads/PDF/ ATEE-2019-ITRE/Book_ itre-2019.pdf

OECD CERI.(2018). 21 ${ }^{\text {st }}$ Century Learning: Research, Innovation and Policy. Directions from recent OECD analyses. OECD Center for Educational Research and Innovation. Iegūts no http://www.oecd.org/site/educeri21st/40554299.pdf

Olina, Z., Namsone, D., France, I. Dudareva, I. (2018). Mācīšanās lietpratîbai, 1., 3. un 8. nod. [Learning for Expertise, Chapters 1, 3, 8] D. Namsones zin. red. Iegūts no https://www.siic.lu.lv/petnieciba/monografija-macisanas-lietpratibai/ 
Pāvula, I. (2008). Kritiskās domāšanas attistïbas pieejas izmantošana izglītibas sistēmā ietekme un efektivitāte Latvijā, 20-27. lpp. [Use of the Approach for the Development of Critical Thinking in Education System - Impact and Effectiveness in Latvia] Izglitības attīstības centra (LAC) projekts. iegūts no http://www.iac.edu.lv/assets/Publications/ Kritiska-domasana-web.pdf

Rubene, Z., Svece, A. (2018). Kritiskā domāšana. Izglīiiba, medijpratiba, spriestspēja, [Critical Thinking. Education, Media-Literacy, Reason] M. Kūles zin. redakcija LU, SIA"Latgales druka" 2. dalia, 13. lpp. Iegūts no https://dspace.lu.lv/dspace/bitstream/ handle/7/45982/Euro_Kritiska_domasanas.pdf?sequence $=1$ \&isAllowed $=\mathrm{y}$,

Sasniedzamie rezultāti kultūras izpratnes un pašizpausmes mākslā mācību jomā [Results achievable in understanding culture self-expressions in art in the field of studies] (2018), Likumi LV, 4. pielikums. Iegūts no https://likumi.lv/ta/id/303768\#piel4

Skolēnam plānotie sasniedzamie rezultāti caurviju prasmēs, beidzot 3., 6.un 9. klasi (2018), [Results planned for a learner to achieve in transversal skills at graduating from gradēs 3, 6, and 9] Likumi LV, 1. pielikums. Iegūts no https://likumi.lv/ta/id/303768\#piel1

Skola 2030. Caurviju prasmes [Transversal skills]. Iegūts no Skola 2030 materiāliem https://www.skola2030.lv/lv/macibu-saturs/merki-skolenam/caurviju-prasmes

Vigotskis, L.. (2002). Domāšana un runa. [Thinking and Speech] Rīga: EVE.

Vilde, I. (2009). Skolēnu darba individualizācija un diferenciācija grupu darbā mūzikas stundā. Radoša personïba VII. [Individualization and Differentiation of Learners' Work in Group Work at a Music Lesson. A Creative Personality] Rīga: RPIVA Kreativitātes zinātniskais institūts, 79.-85. lpp. ISBN 978-9984-39-913-3.

Vilde, I. (2010). Skolēnu radošās pašizpausmes iespējas mūzikas mācībās vispārējās izglītibas iestādēs. [Opportunities for Learners' Creative Self-Expression during Music Studies in General Education Institutions.] ATEE Spring University, Teacher of the $21^{\text {st }}$ Century: Quality Education for Quality Teaching. Rīga: LU, 468.-475. lpp. ISBN 978-9984-49-027-4.

Vilde, I. (2013). Sākumskolēnu muzikalitātes attistïba mūzikas mācībās, [Development of Primary School Learners' Musicality at Music Studies] Promocijas darbs pedagoǵijā. Rīga: LU.

Zariņš, D. (2003). Mūzikas pedagogíijas pamati. [Fundamentals of Music Pedagogy] Rīga: RaKa. 